\title{
STUDY ON A MULTICELL BOX CULVERT TAKING SPAN TO HEIGHT RATIO AND DYNAMIC VEHICULAR LOAD
}

\author{
Kritee Chhetri ${ }^{1}$, Rajendra. $\mathbf{S}^{2}$, Kavitha. $\mathbf{N}^{3}$ \\ ${ }^{\text {I}}$ P.G Student, Department of Civil Engineering, N.C.E.T, Visvesvaraya Technological University, Bangalore, India \\ kriteechhetri@gmail.com \\ ${ }^{2}$ Professor and Head (P.G), Department of Civil Engineering, N.C.E.T, Visvesvaraya Technological University, \\ Bangalore, India \\ rajendra_nulenur@rediffmail.com \\ ${ }^{3}$ Assistant Professor, Department of Civil Engineering, N.C.E.T, Visvesvaraya Technological University, Bangalore, \\ India \\ k316228@gmail.com
}

\begin{abstract}
Box culverts are very important part of a transportation network as they provide an economical alternative to heavy bridges. Box culverts do not require a separate extensive foundation system and they are ideally suited for medium spans. Structurally, box culverts are complicated structures as they are buried completely in soil and because of their self-stabilizing nature. Hence, there is need to for a detailed parametric study on multi-cell box culvert structures in order to understand their structural behavior and to study the influence of various parameters effecting its structural behavior. In the present study span to height ratio of the culvert is analyzed by taking $3 D$ analysis and dynamic vehicular analysis result is compared to a simplified static analysis. An attempt is made to carry out a parametric study on the behavior of a multi cell box culvert subjected to dead loads as well as IRC wheel loadings. The box culverts are modelled using SAP 2000 software using effective width method. IRC 70R loading is used for the analysis and design of culverts. The results of the study reveal that the dynamic study has significant influence on the result of the analysis and should be carefully considered.
\end{abstract}

Keywords: Dynamic Vehicular Analysis, Multicell Box Culvert, Span To Height Ratio, SAP 2000. ****

\section{INTRODUCTION}

RC box culverts are rigid frames which are designed to support vertical loads (earth and vehicular loads) and lateral earth pressure. Box culverts can be either-single cell or multi-cell depending upon its purposes. Box culvert is generally used for the flow of water under a road, railroad, and other obstructions from one side to another. Water can also be allowed to flow above the land through a structure known as aqueduct. Single cell or multi cell box culvert are simple structures but the load applied during the construction and throughout their service life may be complicated. Box culvert was first constructed in Minnesota in 1974 and the structure performed very well. Nowadays, precast box culvert are used to reduce time for plan production and construction. Structure which are under soil i.e. box culvert carries vertical loads through a combination of soil around the structure and the internal capacity, this is known as soil surface interaction. Bridge and culvert does not have much difference because both of them are designed for the purpose of providing passage over the obstacles. The main difference is the span lengthto demarcate between bridge and culvert. If the span is less than $6.5 \mathrm{~m}$ i.e. 20 feet, it is known as culvert and if the span is more than the specified length than it is known as bridge. Box culvert are used to transmit water during runoff period and remains dry rest of the year and is used for wildlife transmission.

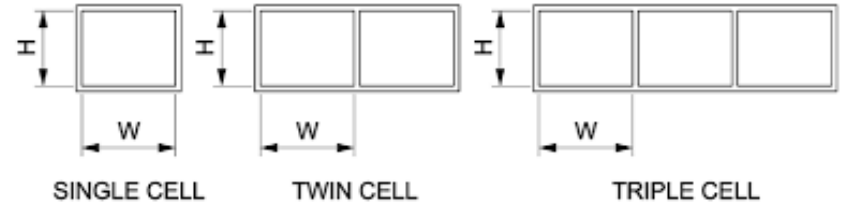

Fig 1: Typical cross-section of box-culvert

\section{COEFFICIENT OF EARTHPRESSURE}

Depending upon the condition of the site, the earth exerts pressure which may be active, passive or the pressure at rest. Box culvert is filled by earth after the construction, now the box is stationary hence the pressure will be at rest.

For the box culvert, the coefficient of earth pressure taken is 0.33 for $\Phi=30$ for active condition from the books of design. Since the earth pressure coefficient has less effect on the structural sizes of the members of the box culvert, hence active pressure will act on box culvert.

\section{EFFECTIVE WIDTH}

Effective width along the width of the culvert is mainly affected by the moving live load. Effective width plays an important role in considering the live load for the design of the culvert without cushion. The live load becomes the main load at the top slab and this load needs to be divided by the 
effective width so as to evaluate the effect per unit run. Effective width is basically the slab width which is perpendicular to the span and is affected by the load applied at the top of the slab.

In order to calculate the effective width an equation for simply supported and continuous slab for different width to span ratio is given in IRC 21-2000. The effective width needs to be calculated for the box culvert so as to evaluate the area affected by the moving load used for the design.

\section{IMPACT OF LIVELOAD}

The impact of the moving load depends upon the type and class of the load. The formula to get the impact factor is given in IRC: 6-2000 Code for different load types. The box culvert with no cushion whose top slab is likely to be subjected to impact needs to be designed for live loads along with the impact loads. There is no effect of impact on the bottom slabs and the vertical walls of the box culvert. Hence it is not considered in design.

\section{BENEFITS OF CULVERT}

Precast box culverts are cost competing with cast in place structures. Box culverts are quick and easy to install. It involves preparation of site, placement and backfilling of box culvert sections. The amount of work on site and the impact of weather on the schedule of the project are reduced by precast fabrication of box culvert. Inspection of the box culvert can be done with an ease. Precast concrete culverts have greater durability and require low maintenance solution. They also have flexibility in design configurations.

\section{LITREATURE REVIEW}

RajendraThakaiet all (2016) have carried out the analytical study of the box girder bridge for rectangular and trapezoidal cross-section. The model is analyzed using the software SAP 2000 which is economically accessible for the finite element analysis. The model is studied for the combination of loads i.e. dead load and live load taken from IRC 70R loading for zero eccentricity for continuous and simply supported span. In this paper, the work is done for the bending moment and longitudinal bending stress in both the top and the bottom flanges. Some of the assumptions which are made during the analysis are:

The vehicular loads taken are from class 70R wheeled vehicle having seven axles given in IRC. The box girder used in this paper is of rectangular and trapezoidal section of single celled box girder bridges.

The study can be concluded by the following conclusions:

- Rise in the depth of the box girder increases the bending moment but decreases the bending stress in both the top and the bottom flange.

- Between the rectangular and the trapezoidal crosssection, the bending moment is highest in trapezoidal section under the combination of loads (DL+LL).
Thus, from the result obtained, it can be said that the rectangular section is stiffer than the trapezoidal section.

PavanD.Tikate and S.N Tande (2015) have carried out a parametric study on box culvert using finite element method and the software used to prepare the modal is STAAD Pro. Here in the paper the analytical study and design of box culvert is carried out considering it as rigid frames and taking the bending moment at theend supports as same. For determining the final moments at the frame joints, moment distribution method is used. For slabs and walls, the moments at midway and supports are determined from different sequences of load and the design of member is performed by taking the maximum moment. From the study it can be concluded there is a little influence of coefficient of earth pressure on the final moments. Hence 0.5 can be taken as coefficient of earth pressure for safety purpose. In this paper, it is noticed that the results of analysis obtained from moment distribution coefficients are in agreement with those obtained by FE method.

NehaKolate et al (2014) have carried out an analytical study on design of RCC box culvert. In this study, they have given a brief idea about a box culvert and usefulness of the box culvert in reducing the flood level. In this paper, the box of $3 \mathrm{mX} 3 \mathrm{~m}$ with and without cushion of $5 \mathrm{~m}$ has been taken. Different load cases are calculated and are checked for shear for the box culvert. The results of analysis and design have discovered that RCC box culvert has many advantages over slab culvert for cross drainage work across high embankment. In box culvert it's easy to add length for widening of road and is structurally rigid and safe. The examination and analysis revealed that box does not need any elaborate foundation, it's easy to construct, requires no maintenance and small variation in coefficient of earth pressure has little influence on the design of box without cushion.

B.N Sinha and R.P Sharma (2009) have worked with box culverts made of RCC without and with the cushion. In this study, design of RCC box culvert has been done manually and by computer method. RCC box culverts are modeled and analyzed using STAAD Pro. The structural design involves consideration of load cases like box empty, full, surcharge load etc. and factors like live load, effective width, impact force, coefficient of earth pressure. Relevant IRC codes are referred in this paper. The designs are done to withstand maximum bending moment and shear force. Effective width in case of box culvert plays an important role without cushion as the live load becomes the main load on the top slab and effective width should withstand this load. Impact of live load, shear stress, distribution reinforcement, load cases have also been discussed in this paper. It has been concluded that the box culvert have more advantages than slab culvert, easy to add length for widening of roads. Box culvert is structurally strong, rigid and safe and does not need any elaborate foundation.

Rahai Ali R (1996) has studied the behavior of buried box culverts. The different parameters taken are earthquake effect and the culvert buried at different depths. The finite element method is used for the linear and nonlinear dynamic 
analysis of modals. Here in this paper two models of dimensions of $8 \times 15 \mathrm{~m}$ and $8 \times 5 \mathrm{~m}$ at the depths of $3.5,7.5$, 15,20 , and 30 meters are used to study the behavior of boxes. For both the linear and nonlinear performances three types of soil, dense, semi dense and soft silty sand have been chosen. The result obtained when the box models were analyzed in two different depths and two different conditions were the tangential stress and the vertical pressure which was executed on the wall of the box. The result also showed that to a certain specified depth, the amount of displacement have increased and decreased consequently. It is seen that the displacement for the nonlinear behavior of the soil is more as compared to the displacement for the linear behavior of the soil. This difference rises as the depth lowers. It is also seen that the decrease in the rigidity decreases the vertical pressure on the walls of the box. It has been concluded that whatever the data obtained from thee analytical study, it shows that the extent of loads exerted and the displacements of the buried box in some parts outstrip the static values.

Ahmed $M$ et al (1993) have studied the behavior of a double cell box culvert. The main parameters taken are the soil pressure, moment and deflection. The main objective of this paper was to provide some information regarding the structural response of full skill functional culvert. For the experimental phase, the culvert selected was double cell cast in place RCC box structure whose inner dimension was $12 \mathrm{ft}$ $\mathrm{X} 12 \mathrm{ft}$, skew angle is 35 " with respect to road way. Permanent fill height was taken as $8.5 \mathrm{ft}$ over the top slab, compaction water content was $21 \%$ - 25\%. Moment measurement was done indirectly by measuring strains in outer and inner reinforcement of concrete wall. The readings were taken periodically during construction and backfilling process. From the obtained result, it was found that negative moment increment was produced in the top slab for the fill height $3.5 \mathrm{ft}$ or less and the height above $3.5 \mathrm{ft}$ moment increment became positive and continued thereafter. Some of the values were predicted and were obtained from a FE solution using CANDE computer program (Culvert Analysis and Design). The conclusion generated after this investigation can be used by either researchers for to verify the field results obtained from the FE computer program.

\section{PARAMETRIC STUDY}

On the box culvertIRC 70R tracked loading is considered. The study is done for variation of bending moment taking dynamic vehicular loading and span by depth ratio. Road bridges and culverts are divided into classes according to loading. In this study, multi cellular box culvert with four span is taken. The dimension of the multi cellular box culvert is taken as per existing culvert. SAP 2000 is to be used for the analysis and design of the culvert. Relevant IRC codes are used i.e. IRC class AA loading or 70R loading as applicable according to IRC.

\section{INFLUENCE OF SPAN TO HEIGHT RATIO OF MULTI-CELL BOX CULVERT FOR DEAD LOAD CASE}

In this part different span to height ratio are taken and maximum negative and positive bending moments are compared for dead load. For this purpose three different culverts with span to height ratio varying from 0.8 to 1.3 are considered.Figure 2, figure 3, figure 4 and figure 5 shows the comparison of span to height ratio for maximum positive and negative bending moment for dead load.

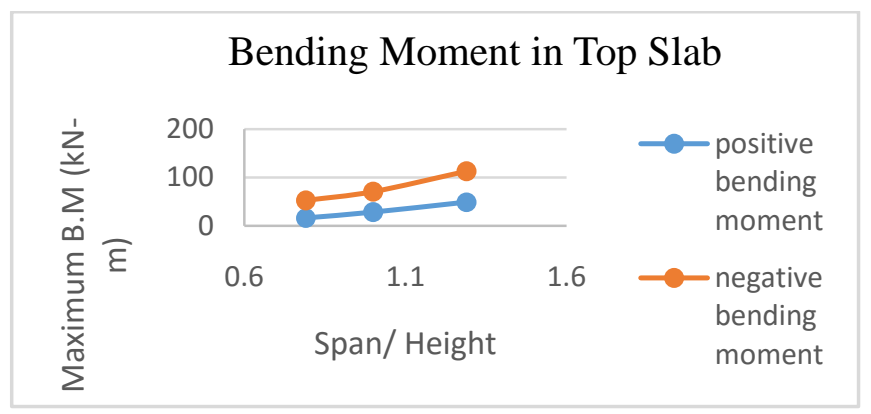

Fig 2: Comparison of maximum positive and negative bending moment with different span to height ratio for top slab for dead load case.

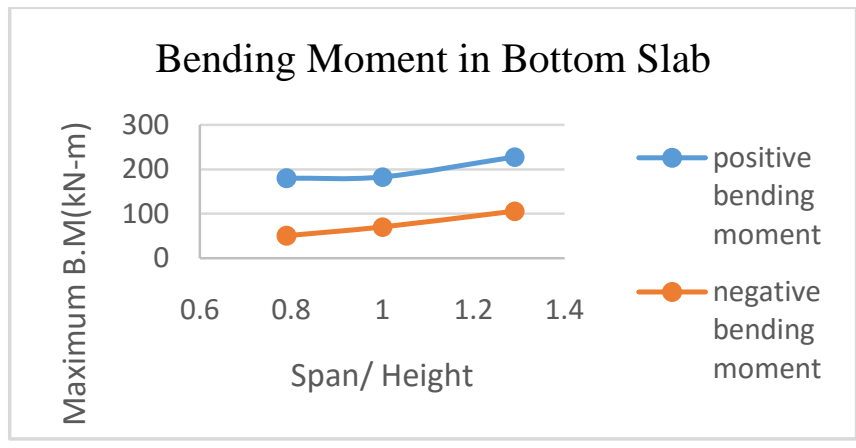

Fig 3: Comparison of maximum positive and negative bending moment with different span to height ratio for bottom slab for dead load case.

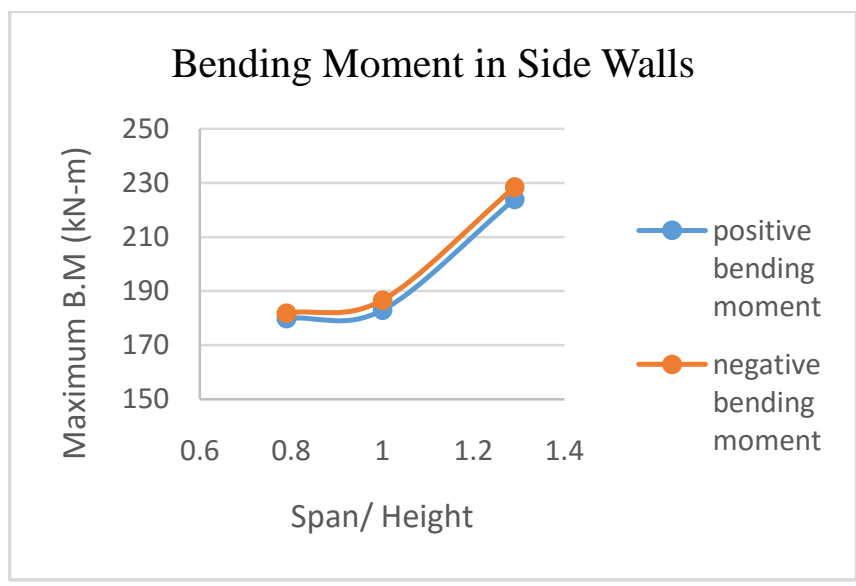

Fig 4: Comparison of maximum positive and negative bending moment with different span to height ratio for side wall for dead load case. 


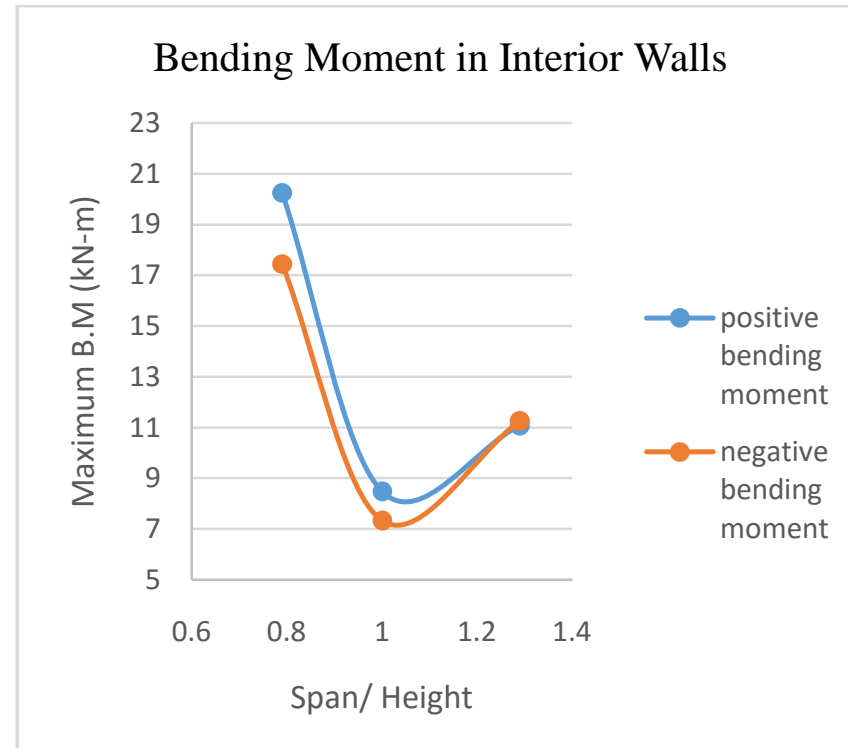

Fig 5: Comparison of maximum positive and negative bending moment with different span to height ratio for interior wall for dead load case.

\section{INFLUENCE OF SPAN TO HEIGHT RATIO OF MULTI-CELL BOX CULVERT FOR WHEEL LOAD CASE}

In this part different span to height ratio are taken and maximum negative and positive bending moments are compared for wheel load. The maximum positive and negative bending moment for wheel load cases are taken for different span to height ratio. Figure 6 , figure 7 , figure 8 and figure 9 shows the comparison of span to height ratio for maximum positive and negative bending moment for wheel load.

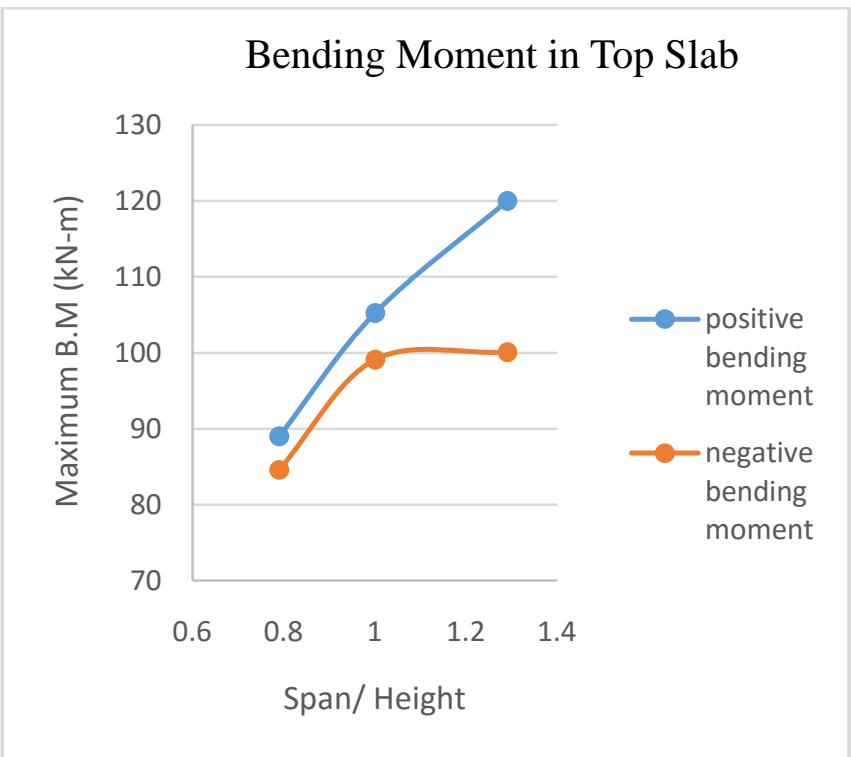

Fig 6: Comparison of maximum positive and negative bending moment with different span to height ratio for top slab for wheel load case

\section{Bending Moment in Bottom Slab}

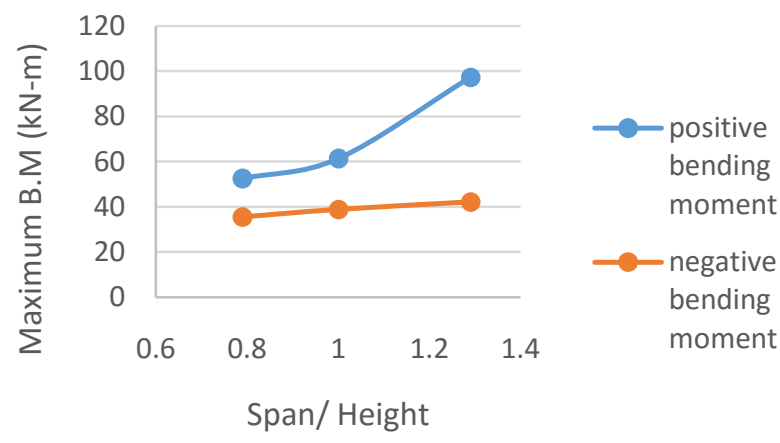

Fig 7: Comparison of maximum positive and negative bending moment with different span to height ratio for bottom slab for wheel load case

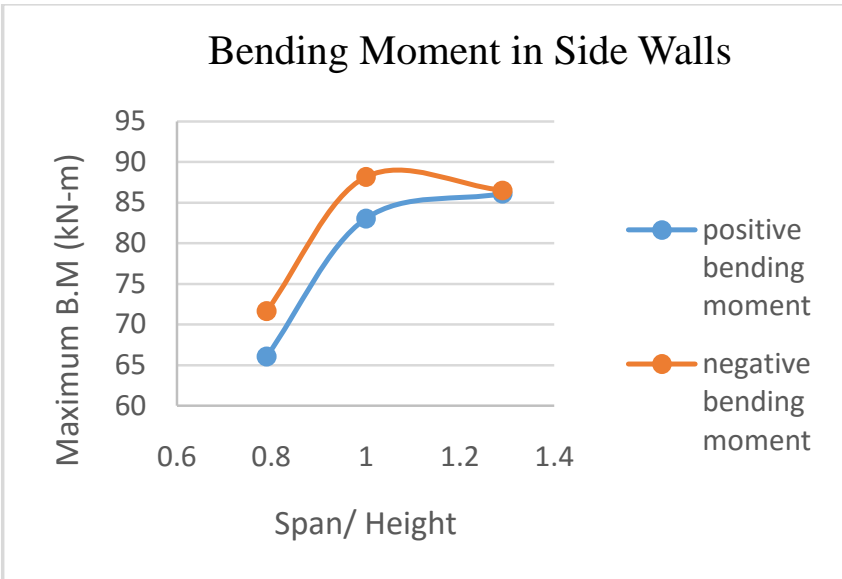

Fig 8: Comparison of maximum positive and negative bending moment with different span to height ratio for side wall for wheel load case

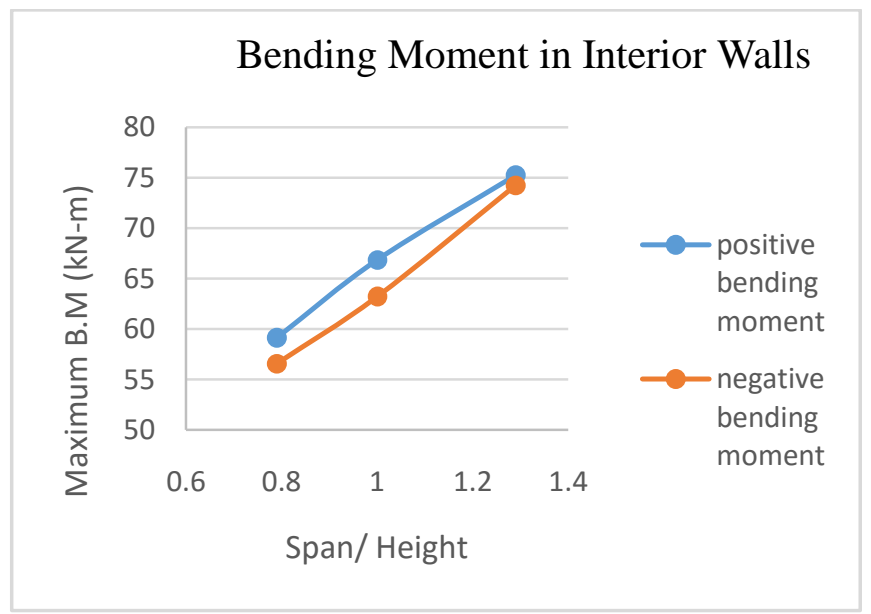

Fig 9: Comparison of maximum positive and negative bending moment with different span to height ratio for interior wall for wheel load case

\section{DYNAMIC VEHICULAR ANALYSIS}

In this part, a multi-cell box culvert subjected to both static and dynamic loads are analyzed. For the static case, mass, speed of the vehicles and the time are not taken into 
account. But in case of dynamic analysis, mass, speed of the vehicles and the time are taken into account. The speed of $80 \mathrm{kN} / \mathrm{hr}$ has been taken for the dynamic load case in the present problem. The analysis is done using SAP 2000 software. SAP 2000 converts the vehicular movement into a time history function and hence from this, time history analysis is carried out.

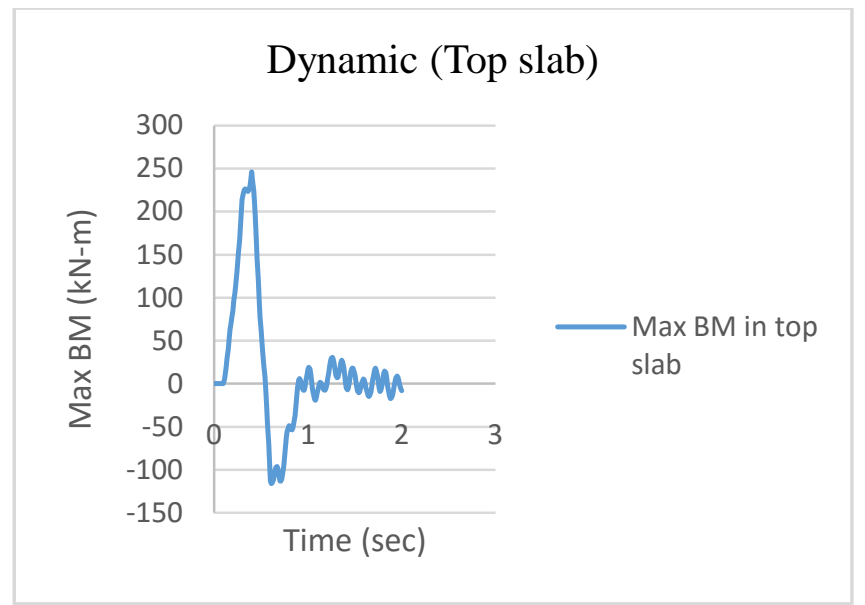

Fig 10: Maximum Bending at top slab due to dynamic vehicular loading

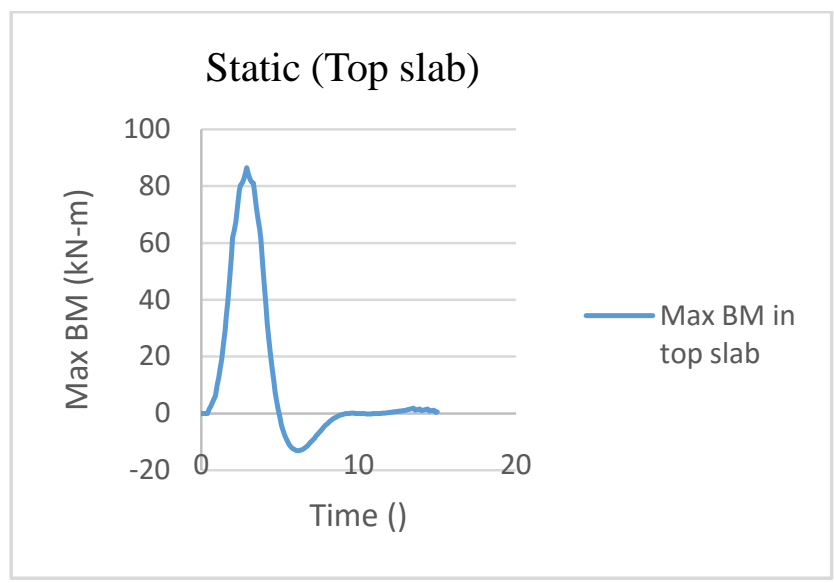

Fig 11: Maximum Bending at top slab due to static vehicular loading

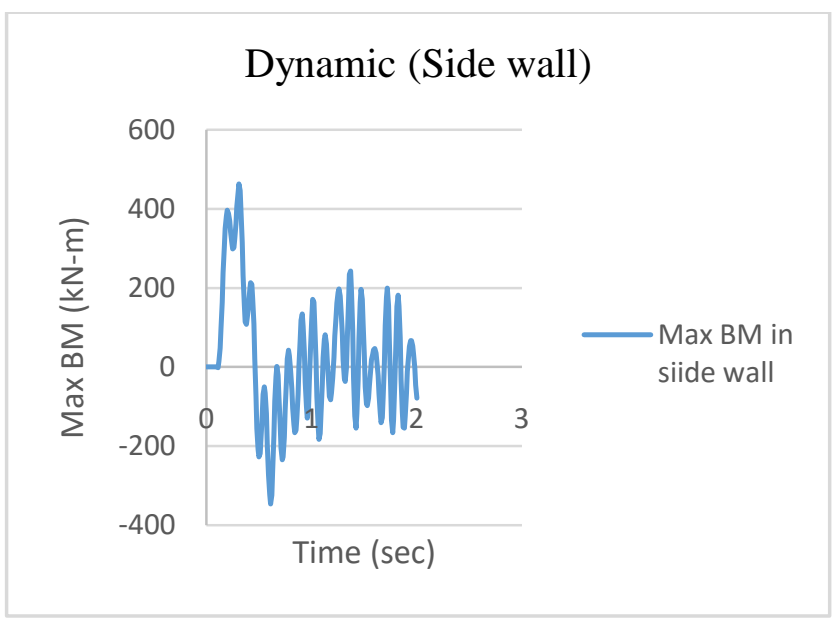

Fig 12: Maximum Bending at side wall due to dynamic vehicular loading

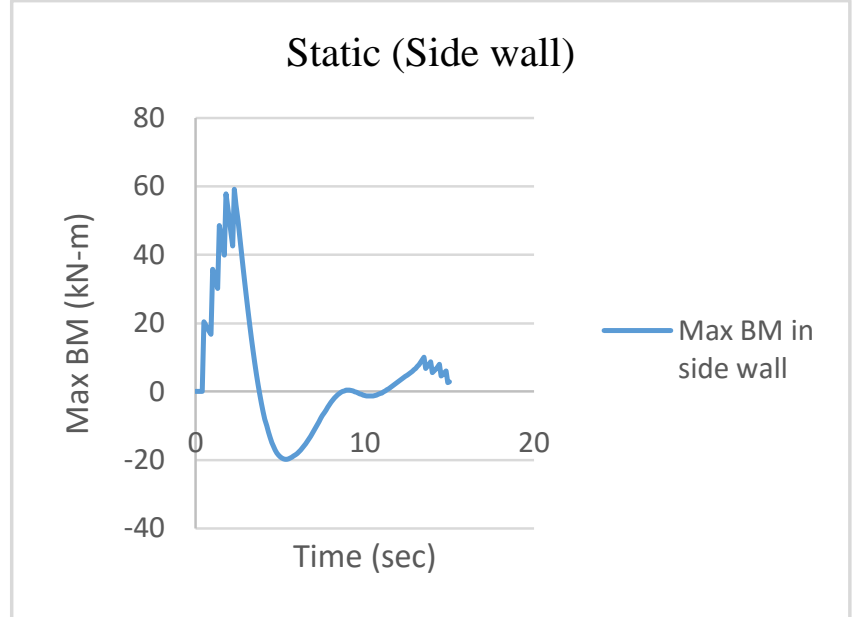

Fig 13: Maximum Bending at side wall due to static vehicular loading

\section{CONCLUSION}

$>$ SAP 2000 has proved to be an efficient tool to analyse multi-cell box culvert both by effective width as well as by $3 \mathrm{D}$ finite element analysis.

$>\quad$ The change in span to height ratio of the culvert alters the relative stiffness of various members in the culvert and hence affects the internal forces in the members. The results of bending moments have shown considerable variations with the span to height ratio of culverts.

$>$ Vehicular dynamic analysis has revealed that the maximum bending moment occurs for the dynamic vehicular load case. In case of top slab maximum bending moment is $65 \%$ more with dynamic case and in case of side wall maximum bending moment is $85 \%$ more with dynamic case. Hence, it can be said that for a multicellular box culvert dynamic vehicular loading analysis is necessary.

\section{ACKNOWLEDGEMENT}

First and foremost we would like to thank our Principal for guiding us in the right direction and helping us with his valuable suggestions. We are also grateful to the authors of various papers and journals cited in our research paper. Lastly we would like to thank our friends, family and the Department of Civil Engineering for providing us with their support and help.

\section{REFERENCES}

[1]. Ahmad M. Abdel-Karim, Maher K. Tadros on "Structural Response of Full-Scale Concrete Box Culvert". Journal of Structural Engineering, 1993.

[2]. B.N.Sinha, R.P.Sharma on "RCC Box Culvertmethodology and Design Including Computer Method". Journal of the Indian Roads Congress (JIRC), December 2009, pp 555.

[3]. IRC (Indian Road Congress): 6-2000, Standard Specifications and Code of Practice for Road Bridges.

[4]. NehaKolate, Molley Mathew, Snahal Mali on "Analysis and Design of RCC Box Culvert". 
International Journal of Scientific and Engineering Research (IJSET), ISSN: 2229-5518, Vol 5, December 2014.

[5]. PavanD.Tikate, S.N.Tande on "Design Based Parametric Study of Box Culvert using Finite Element Method". Journal of Basic and Applied Engineering Research, ISSN: 2350-0077, Vol 2 No 17, September 2015, pp 1490-1495.

[6]. Rahai Ali R on "Investigation of Earthquake Effect on Buried Box Culverts". Elsevier Science Ltd 1996, paper no 216.

[7]. RajendraThakai, Raghunath Deshpande, ShantinathBedkihal on "Parametric Study on Behavior of Box Girder Bridges using Finite element Method". International Research Journal of Engineering and Technology (IRJET), ISSN 2395-0056, Vol 03, August 2016.

[8]. SujataShreedhar, R. Shreedhar on "Design coefficients for single and two cell box culvert". International Journal of Civil and Structural Engineering, Volume 3, No 3, 2013, ISSN 0976 - 4399

[9]. Bowles, J.E. (1988) Foundation analysis and design, $4^{\text {th }}$ Edition, McGraw-Hill.

[10]. IS 456-2002: "Plain and Reinforced Concrete", Bureau of Indian Standards New Delhi.

[11]. SP 16 Design Aids for Reinforced Concrete", Bureau of Indian Standards New Delhi.

[12]. "Design of Bridges"- N Krishna Raju, Oxford \& IBH Publishing Co New Delhi. 